1 Title: Remote sensing based change analysis of rice environments in

\title{
Odisha, India
}

5 Keywords: rice cultivation, MODIS, stress-tolerant varieties, drought and submergence, 6 Odisha.

9 Authors: Murali Krishna Gumma ${ }^{\mathrm{a}, \mathrm{b}^{*}}$, Samarendu Mohanty ${ }^{\mathrm{b}}$, Andrew Nelson ${ }^{\mathrm{b}}$, Rala

$10 \quad$ Arnel $^{\mathrm{b}}$, Irshad A Mohammed ${ }^{\mathrm{a}}$ and Satya Ranjan Das ${ }^{\mathrm{c}}$

$12{ }^{a}$ International Crops Research Institute for the Semi-Arid Tropics, Patancheru-502324,

13 India

$14{ }^{\mathrm{b}}$ International Rice Research Institute, DAPO Box 7777, Metro Manila, Philippines.

15 ' Orissa University of Agriculture and Technology, Odisha.

$19 *$ Corresponding authors

20 Dr. Murali Krishna Gumma, International Crops Research Institute for the Semi-Arid Tropics,

21 Patancheru-502324, India, Tel: +91 (40) 30713071 ext: 2449, Fax: +91 (40) 30713074.

22 E-mail: m.gumma@cgiar.org.org 


\section{India}

\section{Abstract}

4 The rainfed rice-growing environment is perhaps one of the most vulnerable to water

5 stress such as drought and floods. It is important to determine the spatial extent of the

6 stress-prone areas to effectively and efficiently promote proper technologies (e.g., stress-

7 tolerant varieties) to tackle the problem of sustainable food production. This study was

8 conducted in Odisha state located in eastern India. Odisha is predominantly a rainfed rice

9 ecosystem (71\% rainfed and 29\% canal irrigated during kharif-monsoon season), where

10 rice is the major crop and staple food of the people. However, rice productivity in Odisha

11 is one of the lowest in India and a significant decline (9\%) in rice cultivated area was

12 observed in 2002 (a drought year). The present study analyzed the temporal rice cropping

13 pattern in various ecosystems and identified the stress-prone areas due to submergence

14 (flooding) and water shortage. The spatial distribution of rice areas was mapped using

15 MODIS (MOD09Q1) 250-m 8-day time-series data (2000 to 2010) and spectral matching

16 techniques. The mapped rice areas were strongly correlated $\left(\mathrm{R}^{2}=90 \%\right)$ with district-level

17 statistics. Also the class accuracy based on field-plot data was $84.8 \%$. The area under the

18 rainfed rice ecosystem continues to dominate, recording the largest share among rice

19 classes across all the years. The use of remote-sensing techniques is rapid, cost-effective,

20 and reliable to monitor changes in rice cultivated area over long periods of time and

21 estimate the reduction in area cultivated due to abiotic stress such as water stress and

22 submergence. Agricultural research institutes and line departments in the government can 
1 use these techniques for better planning, regular monitoring of land-use changes, and

2 dissemination of appropriate technologies.

3

4 Key words: rice cultivation, MODIS, stress-tolerant varieties, drought and submergence,

5 Odisha..

6

7 Introduction

8 Odisha is an agrarian state with agriculture and allied sectors contributing to

9 nearly $22 \%$ of the state gross domestic product in $2009-10$. Nearly $70 \%$ of the total

10 workforce is directly or indirectly employed by this sector. Despite its importance in the

11 state economy, agricultural production still depends on the mercy of the rain god. More

12 than half of the 9 million hectares of total cropped area in 2008-09 depended on

13 monsoon. Odisha, an eastern state with more than 9 million hectares of total cropped area,

14 has been plagued by one or multiple stresses (drought, submergence and salinity) in most

15 of the years during the last four decades. Rice is a major cereal grown in the state, with

16 nearly 5 million hectares of area (884,282 ha of kharif-autumn rice, 3,401,572 ha kharif-

17 winter rice, and 884,282 ha of rabi-summer rice) and $71 \%$ of the total rice crop is rainfed.

18 More than $90 \%$ of the total rice is grown in the kharif season, accounting for two thirds of

19 the total kharif cropped area. The plateau terrain of the state, with yellow laterite and

20 lateritic soils, is low in organic matter and NPK, accounting for $60 \%$ of the state's rice

21 area. The remaining $40 \%$ of rice is grown in the coastal belt with alluvial soil, which is

22 generally fertile but low in nitrogen and phosphorus. The lower yield of paddy in the state

23 could be explained to the lack of proper infrastructure, including irrigation facilities, 
1 input availability, output marketing, transportation, and storage; socioeconomic

2 conditions of the farmers; and the size of landholdings.

4 In the last 50 years, Indian rice production has nearly tripled with the introduction of

5 semi-dwarf modern varieties, as part of the Green Revolution package. During this period,

6 production has been kept up with population growth, with a steady increase in per capita

7 production in the 1970 s and 1980s, before flattening out in the 1990s, and finally

8 declining in the 21st century (Fujita, 2009). Historically, the eastern states of India had

9 low productivity, especially Odisha, one of the lowest (1.5 t/ha). However with an

10 increase to 2.5 tons/ha recently it is below the national average of 3 tons/ha. More than

$1190 \%$ of the rice area is rainfed. Poor infrastructure, inadequate credit, small land holdings,

12 imbalanced fertilization have added to the difficulties to farmers including poor seed

13 replacement rate. Erratic behavior of the monsoon has also led to variation in paddy

14 yields over the years to make things worse. There is need to focus technology packages to

15 improve yields in the rainfed systems taking into account the drought in the upland rice

16 areas and submergence in the rainfed lowlands(Das and Bastia, 2013).

17 Several studies were conducted in different parts of the world using various

18 remote-sensing techniques at different resolutions (Abderrahman and Bader, 1992;

19 Ambast et al., 2002; Frolking et al., 2002; Sakamoto et al., 2006; Gumma et al., 2011a).

20 Previous studies have reported the advantages of MODIS (moderate-resolution image

21 spectroradiometer) satellite imagery in mapping agricultural changes between water-

22 surplus and water-deficit years, including the dynamics of change in agriculture (Gaur et

23 al., 2008; Biggs et al., 2010; Gumma et al., 2011c). Providing insights and methods for 
1 measuring short- to long-term changes in land use (Singh, 1989; Coppin et al., 2004; Lu

2 et al., 2004), these studies have been done for a few years. Identifying crop land changes

3 is very important for sustainable agriculture and livelihoods (Gautam et al., 2003;

4 Semwal et al., 2004; Gumma et al., 2011a). However, it is seldom used to identify how

5 rainfed rice areas change in response to variations in climate for improving food

6 production and livelihood.

7 Since two-thirds of the total rice area is not irrigated, priority should be given to

8 improving productivity in rainfed systems. The diverse ecosystems under which rice is

9 grown within the rainfed region, blanket technology package for the entire region will not

10 suffice and careful evaluation is needed to develop a customized technology package for

11 each ecosystem. The main objective of this study is to map the rice areas in Odisha from

12 2000-01 to 2010-11 using MODIS 250-m 8-day time-series data using spectral matching

13 techniques and identify stress-prone rice areas in the state. The information generated can

14 potentially guide rice scientists and planners in developing technologies suited to rainfed

15 conditions and other rice ecosystems as well as in targeting technologies adapted to local

16 needs. Moreover, the information could be used to develop stress-adaptive measures and

17 technologies focusing on the most vulnerable areas where drought is most severe and

18 where rainfed rice production is the major livelihood of farmers.

\section{$20 \quad 2.0$ Study areas}

21 Odisha is located in the subtropical zone in the eastern region of India between $17^{\circ} 31{ }^{\prime} \mathrm{N}$

22 and $20^{\circ} 31^{\prime} \mathrm{N}$ latitude and $81^{\circ} 31^{\prime} \mathrm{E}$ and $87^{\circ} 30^{\prime} \mathrm{E}$ longitudes (Fig. 1). It is bounded by

23 Jharkhand to the north, Chhattisgarh to the west, Andhra Pradesh to the south, West 
1 Bengal to the northeast, and the Bay of Bengal to the southeast. The mountain ranges of

2 the Eastern Ghats run from northeast to southwest in the middle of the state. These

3 mountain ranges separate the eastern part of the state, which is a coastal belt with $482 \mathrm{~km}$

4 of coastline, and the western part, which is an extensive plateau. The state has a

5 geographical area of 15.571 Mha. The state has been divided into four physiographic

6 divisions: the Northern Plateau (25.5\% of total geographical areas), Central Table Land

7 (24.1\%), Eastern Ghat Region (29.2\%), and Coastal Region (21.2\%).

9 Odisha, lying just south of the Tropic of Cancer, has a tropical climate. The

10 climate is hot, moist, and sub-humid. The average rainfall is $1597 \mathrm{~mm}$ over 77 rainy 11 days; $80 \%$ occurs in the monsoon season (during June to September) (Panigrahi et al., 12 2010). Odisha has five major irrigation projects, the Hirakud, Rangali, Indravati, Kolab,

13 and Balimela reservoirs (Fig. 1), which can irrigate almost 3 million hectares, and within

14 which rice is one of the most dominant crops. Rice is the major crop and staple food of

15 the people in Odisha, mainly grown in the kharif season (predominantly rainfed rice),

16 which contributes $94 \%$ of total rice and $92 \%$ of total rice production in Odisha (Samal 17 and Pandey, 2005).

\section{$19 \quad 3.0$ Data sets}

\section{$20 \quad 3.1$ Satellite data}

21 The MODIS terra 8-day time-series data for Odisha were downloaded from calibrated

22 global continuous time-series mega-data sets composed from individual files of NASA

23 (www.modis.land.gsfc.nasa.gov). The MOD09Q1 2000 to 2010' (Table 1) Terra sensor 
1 data in two specific bands were processed for land applications as a MODIS surface

2 reflectance product. The product is an estimate of the surface reflectance for each band as

3 it would have been measured at ground level if there were no atmospheric scattering or

4 absorption. Original MODIS data were acquired in 12-bits, and were stretched to 16-bits.

5 Furthermore, the rate of observation coverage, the viewing angle, cloud or cloud shadow

6 coverage, and aerosol loading were all assessed on a pixel-by-pixel basis to ensure that

7 each pixel contained the best observation during that 8-day period. MODIS 8-day

8 composites were used to calculate two indices: (a) normalized difference vegetation

9 index (NDVI) and (b) NDVI monthly maximum value composites (NDVI MVC), using

10 surface reflectance values from red $(620-670 \mathrm{~nm})$ and NIR1 $(841-875 \mathrm{~nm})$ bands with the

11 following equations. In our study, monthly NDVI MVC were used for classification and

12 an NDVI 8-day data set was used for identifying and labeling seasonal rice classes.

13

$$
N D V I=\frac{\lambda_{N I R}-\lambda_{\text {red }}}{\lambda_{\text {NIR }}+\lambda_{\text {red }}}
$$

$$
N D V I_{M V C_{i}}=\operatorname{Max}\left(N D V I_{i 1}, N D V I_{i 2}, N D V I_{i 3}, N D V I_{i 4}\right)
$$

17 where $M V C_{i}$ is the monthly maximum value composite of the $\mathrm{i}^{\text {th }}$ month and $\mathrm{i}_{1}, \mathrm{i}_{2}, \mathrm{i}_{3}$, and

$18 \mathrm{i}_{4}$ are every 8 days' data in a month. 
1 Field-level surveys were conducted during August 30-September 28, 2005, and August

2 16-August 25, 2010, across 146 locations covering the major rice-growing areas in

3 Odisha (Figure 1). Main purpose of field-plot data is to class identification and validation

4 of resultant classified output. Location-specific data were collected from $500 \mathrm{~m}$ x $500 \mathrm{~m}$

5 plots consisting of GPS locations, land use categories, land cover percentages, cropping

6 pattern during different seasons (through farmer interviews), crop types, and irrigation

7 method (irrigated or rainfed). Field-plot samples were obtained within large contiguous

8 areas of a particular land use/land cover (LULC). The locations were chosen based on the

9 knowledge of local agricultural extension officers to ensure that the same crops were

10 grown during previous years as were observed during the survey. The local experts also

11 provided information on crop calendars, cropping intensity (single or double crop,

12 including crop types), irrigation application, and percentage canopy cover for these

13 locations from their recorded data for the previous years. Overall, 114 spatially well-

14 distributed data points (Figure 1) were collected. These field-plot data were used for

15 identification and labeling class names (50 field-plot data) and also used for accuracy

16 assessment (96 field-plot data).

$18 \quad 3.3$ District statistics for rice

19 Statistics on rice cultivated area, production, and price were obtained at the sub-national

20 level (districts) from the Datanet India private limited (DIP, 2012). The information was

21 also supplemented by the state agriculture department of Odisha. The amount of area

22 cultivated for rice from the district statistics is mainly used to cross-check the amount of 
1 rice area obtained from remote-sensing techniques, while the rice varietial data are used

2 for estimating rainfed/irrigated rice varieties, including hybrid/stress-tolerant varieties.

\section{$4 \quad 3.4$ TRMM rainfall data}

5 Daily rainfall data for Odisha were downloaded from the Tropical Rainfall Measuring

6 Mission (TRMM) (TRMM, 2012) and processed as monthly rainfall to compare with 11

7 years (from 2000 to 2010) of monthly mean rainfall data. Also, monthly rainfall data

8 were obtained from the Indian Institute of Tropical Meteorology (IITM, 2012).

\section{$10 \quad 4.0$ Methods}

11 An overview of the methods is shown in Figure 2 and details are described below.

12 The process starts with mapping temporal rice areas using MODIS 8-day time-series data

13 with spectral matching techniques and field-plot information. Accuracy assessment was

14 performed with district-wise national statistics and field-plot data, then calculating sub-

15 pixel areas with field-plot data. Finally, stress-prone areas with changes in rice-growing

16 areas with monthly rainfall data were identified.

Insert Fig. 2 here

\section{$19 \quad$ 4.1 Mapping rice areas}

20 MODIS 250-m spatial resolution 8-day time series of normalized difference vegetation

21 index (NDVI) data (extracted from MOD09Q1 surface reflectance product) were used to

22 map rice areas using spectral matching techniques, following the methodology adopted

23 from Thenkabail et al. (2007). MODIS 8-day NDVI images were processed and stacked 
1 into a single composite for 2000-01 (46 NDVI images), 2001-02 (24 NDVI images),

2 2002-03 (24 NDVI images), 2003-04 (24 NDVI images), 2004-05 (24 NDVI images),

3 2005-06 (24 NDVI images), 2006-07 (24 NDVI images), 2007-08 (24 NDVI images),

4 2008-09 (24 NDVI images), 2009-10 (24 NDVI images), and 2010-11 (46 NDVI

5 images). Thus, a total of eleven image composites were developed. The time series for

6 each year was stacked for the kharif season, which runs from June to October/November,

7 but we stacked June to December to consider late-sown crops as well.

8 Each year, MODIS NDVI time series composite was then classified using

9 unsupervised ISOCLASS cluster K-means classification with a convergence value of

100.99 and 100 iterations, yielding 100 classes followed by successive generalization..

11 Unsupervised classification was used instead of supervised classification in order to

12 capture the range of variability in phenology over the image across the study area. The

13 initial number of classes varied from 100 to 150 based on the area covered by the

14 segment and the complexity of the area.

15 Land use/land cover class identification and labeling were based on MODIS

16 NDVI time-series plots, ideal spectra, ground-truth data, and very high resolution images

17 (Google Earth). Ideal spectra were generated using time series imagery with precise filed

18 plot data of same type of land use at spatially distributed locations. The specific protocols

19 included grouping class spectra based on class similarities and/or comparing them with

20 ideal/target spectra, rigorous protocols for class identification, and labeling with the use

21 of large volumes of ground-truth data and very high resolution imagery. After rigorous

22 classification process most of the classes were identified except some mixed classes

23 (Thenkabail et al., 2007, Gumma et al., 2011b, Gumma et al., 2011c). The processes 
1 were followed by resolving mixed classes through specifying GIS spatial

2 analysis/modeling layers (DEM/rainfall).We established methods for area calculations

3 and accuracy assessments. Once the classes were identified, we combined the similar

4 classes by visual matching using spectral correlation coefficient within the classes using

5 equation 3. The spectral correlation coefficient is a combination of signature shape and

6 magnitude (Thenkabail et al., 2007):

$$
S C C=\frac{1}{n-1} \sum_{i=1}^{n}\left(\frac{x_{i}-x_{\text {mean }}}{s_{x}}\right)\left(\frac{y_{i}-y_{\text {mean }}}{s_{y}}\right)
$$

8 where, "SCC" is spectral correlation coefficient, " $n$ " is number of NDVI-MVC, " $x_{i}$ " is

9 NDVI of $i^{\text {th }}$ month in $x$ class, " $x_{\text {mean }}$ " is mean NDVI of $x$ class, " $s_{x}$ " is mean NDVI of $x$

10 class, " $y_{i}$ " is NDVI of $i^{\text {th }}$ month in $y$ class, " $y_{\text {mean }}$ " is mean NDVI of $y$ class, and " $s_{y}$ " is

11 the mean NDVI of $y$ class.

12 Spectral correlation coefficient is a combination of signature shape and magnitude.

13 Class signatures with the closest correlation (coefficient $0.90-1.0$, coefficients of irrigated

14 rice classes varying from 0.95 to 1.0 ) were assigned the same class name for all the time

15 periods. The classes generated from the unsupervised classification were aggregated into

1615 classes and named on the basis of spectral similarity. Spectral matching was used to

17 relate the classes for all years (Thenkabail et al., 2005; Thenkabail et al., 2007;

18 Thenkabail et al., 2009; Gumma et al., 2011b). These processes are briefly explained in

19 Thenkabail et al. (2007).

20 After rice areas were mapped, precise areas in each rice class for Odisha were

21 calculated. However, in coarser resolution MODIS with $250 \mathrm{~m}$ on a side (pixel size), 
1 which was larger than many agricultural fields in the study area, the sub-pixel rice

2 fractions were determined using intensive field-plot information (Gumma et al., 2011b).

$4 \quad 4.2$ Accuracy assessment

5 Accuracy assessment was performed based on two methods: First was to correlate

6 between national statistics and MODIS-derived irrigated areas and the second was based

7 on MODIS-derived irrigated areas evaluated with field-plot information through error 8 matrix.

9 The final rice map was compared against the yearly district-wise rice area

10 statistics of Odisha (Odisha Department of Agriculture and Statistics). The MODIS rice

11 area fractions were aggregated to get the total mean rice areas from 2000 to 2009 and

12 these were compared with the reported planted mean rice areas from 2000 to 2009 at the

13 district level. Furthermore, the data sets generated from remote sensing were validated

14 based on the intensive field-plot data.

15 Based on a theoretical description given by (Jensen, 2004), to generate an error

16 matrix. The columns of an error matrix contain the field-plot data points and the rows

17 represent the results of the classified rice maps (Congalton, 1991). The error matrix is a

18 multi-dimensional table in which the cells contain changes from one class to another

19 class (Congalton and Green, 1999), equations 4, 5, and 6 were used to estimate accuracies 20 and errors.

\section{$22 \quad 4.4$ Rice-growing areas}


1 The MODIS-derived rice area maps for 2000-01 and 2010-2011 were used as the basis of

2 the maximum possible extent of rice areas. As such, the 2000-01 map is the best available

3 and most detailed map of the rice area in India (Gumma et al., 2011b). Based on our field

4 knowledge and extension officer's knowledge of the area, we hypothesize that there was

5 significant change in the potential area that could be planted to rice between 2000 and

6 2010. Almost all gains in productivity are due to increased yields rather than agricultural

7 expansion.

\section{$9 \quad 4.5$ Identifying changes using spectral matching techniques}

10 A comparison between total rice area and yearly rice area was made (section 4.4). If the

11 rice class was identified as 'other class', then observed monthly rainfall was compared

12 with normal monthly rainfall using spectral matching techniques. Spectral matching

13 techniques (SMTs) match the rice class spectra extracted from a good year with rice with

14 other class spectra extracted from a water-deficit or submergence year. We identified the

15 duration, magnitude, and peak of NDVI. A higher value of NDVI was noticed during the

16 kharif season (with the peak of NDVI observed during September) compared with the

17 rabi season for land use change areas. For Odisha, the highest value of maximum mean

18 NDVI was 0.8 during the kharif rice season, but the value of NDVI was never above 0.4

19 in any of the months during seasons of water deficit/submergence years.

\section{$21 \quad 5.0$ Results \& Discussion}

22 Results focus on a temporal analysis with changes in rice area mapping over the years,

23 rice classification and accuracy assessment based on field-plot data with spectral 
1 matching techniques, and comparison between MODIS rice area estimates and national

2 and sub-national statistics for Odisha. Comparative rainfall and NDVI trends for water

3 deficit/submergence and normal years are used for identifying stress-prone districts for

4 the dissemination of stress-tolerant varieties.

\section{$6 \quad 5.1$ Rice maps and statistics}

7 Rice classes identified based on field-plot data include GPS-referenced digital images

8 and temporal NDVI signatures for each of the rice classes (Thenkabail et al., 2007;

9 Gumma et al., 2011b). Six rice classes were identified and labeled in various eco-regions

10 (Fig. 3), such as rainfed-single crop, groundwater-double crop, irrigated-single crop,

11 Irrigated-surface water/groundwater-double crop irrigated-surface water and groundeater-

12 double crop and irrigated triple crop. Area statistics are shown in Table 2. Rice areas

13 were mapped for the last 11 years. But, 2010-11 will be the focus of the discussion (Fig.

14 3). Irrigated areas are mainly located under major irrigation projects that are spatially

15 spread out in the districts of Baragarh, Cuttack, Jagatsinghpur, Khordha, Kalahandi, Puri,

16 Baleswar, Sambalpur, and Sonpur (Fig. 1). Irrigated single crop rice is located in Bhadrak

17 and Ganjam. Rainfed single crop rice area is distributed all over the study area, but the

18 major areas are located in Bolongir, Nuapada, Nabrangpur, and Malkangiri districts.

19 The Ministry of Agriculture reported net rice areas of about 4.21 million hectares

20 in various eco-systems. Figure 3 (2010 rice map) shows almost the same rice-growing

21 areas: net irrigated rice was 1.87 million hectares and rainfed rice areas (Table 2) (kharif

22 season) were 2.4 million hectares.

Insert Figure 3 here 


\subsection{Accuracy assessment based on field-plot data}

5 A quantitative accuracy assessment was performed through error matrix whether a known

6 rice area is classified as rice (without type of irrigation) or non-rice. This process was

7 done using 96 independent field-plot observation points and they are summarized in

8 Table 3. Each of the field-plot points refers to one of seven classes. The user accuracy

9 varied from $76 \%$ to $100 \%$ across seven classes, with an overall accuracy of $77.08 \%$.

10 However, it must be noted that most rice classes are inter-mixed (rainfed rice mix with

11 irrigated-surface water rice class). So, if we combine all six rice classes into one rice

12 class, the accuracy of rice mapping will be very high (about $90 \%$ ). So, the uncertainty of

13 about $20 \%$ is due to the inter-mix among the various rice classes. Therefore, accuracy

14 will be very high between rice and non-rice classes. The irrigated classes generally have

15 higher classification accuracies than the rainfed or mixed irrigated/rainfed classes (Table $163)$.

Insert Table 3here

\section{$18 \quad 5.3$ Comparison with national statistics}

19 District rice area statistics obtained through MODIS derived rice map were in good

20 agreement across all classes with published rice statistics (Fig. 4). We performed a

21 comparison at the district level (30 spatial units) across the study area, and we calculated

22 the mean of the district rice areas for both MODIS derived rice areas and national

23 statistics. The degree of agreement between the MODIS derived rice area estimates and

24 the published statistics is very high $(89.48 \%)$ at the district level, indicating the reliability

25 and accuracy of the results obtained and of the conclusion drawn. Although some districts 
1 had rice area over- or under-estimated, we believe that these estimates are correct because

2 remote-sensing techniques are a more scientifically valid measure.

\section{$5 \quad 5.4$ Temporal changes in rice-growing area}

6 Temporal variations in rice-growing areas in Odisha from 2000 to 2010 at the district

7 level are shown in Figure 5. During the period 2000-2010 the stress prone years were

8 grouped into 5 types: 1. normal rice areas and 2. partial damaged area due to drought 3.

9 complete damage due to due to drought 4. partial damage due to floods and 5. complete

10 damage due to floods Table 3. In the last decade, 2002 had the lowest total rice area in

11 Odisha, with an estimated rice area of 3,048,376 ha $(149,348$ ha of complete damage and

$121,379,195$ ha of partial damage; see Table 4), compared with the average of the 11 years.

13 This reduction in rice area was brought about by a severe incidence of water stress as

14 indicated by the data on low rainfall. The average rainfall for severe drought-affected

15 areas in 2002 was only $840 \mathrm{~mm}$ compared with the normal rainfall of 1,498 $\mathrm{mm}$.

16 Similarly, mean NDVI was 0.62 in normal years compared with only 0.42 for drought

17 year 2002 (Gumma et al., 2011a). The data for a normal year is the average value for the

18 last 50 years (1960-2009) for both mean monthly rainfall and NDVI generated from the

19 remote-sensing database.

20 The western districts of Odisha (mainly Baragarh, Bolangir, and Nabarangpur)

21 were severely affected by drought in 2002: there was an estimated more than $30 \%$

22 reduction in rice area planted due to the low and uneven rainfall distribution during rice

23 planting and early crop growth (Table 4). Some districts were affected by flooding that 
1 occurred in the latter part of the rice-growing season during 2007-10 in coastal districts

2 (mainly in Bhadrak, Kendrapara, and Puri).

\section{$6 \quad 5.5$ Identification of stress-prone areas}

7 In order to identify the frequency of drought and submergence years, the stress prone

8 areas are grouped into 3 classes of frequency of drought and 3 classes of frequency of

9 submergence (Figure 6 and Table 5).,It provides information on prioritizing areas that are

10 often affected by stress.

11 It can be observed that 1,761,988 ha were affected by water deficiency 1-2 times

12 (mainly in 2000, 2002, and 2009) in 11 years while 1,163,800 ha were affected 3-5 times.

13 A relatively small area $(188,856 \mathrm{ha})$ was affected by more than five occurrences of water

14 deficiency. More than half $(57 \%)$ of the total rice area of Bolangir $(161,707$ ha) was

15 affected by one to two occurrences of water deficiency. Sundargarh, although ranking 9th

16 in terms of rice area $(171,225$ ha), was greatly affected by water deficiency, with $52 \%$

17 affected rice area (3-5 times) and 16\% affected rice area (more than 5 times).

18 Submergence (flooding) was also observed but it was not as spectacular as the

19 extent and occurrence of water deficiency. Only 5\% (not more than 215,000 ha) of the

20 total Odisha rice area was affected, with Bhadrak having the highest percentage of

21 submerged rice area of 35\% (1-2 times), 29\% (2-5 times), and 4\% (more than 5 times).
Insert Fig. 6 here

Insert Table 5 here 


\section{$2 \quad 5.6$ Rice production planning and targeting}

3 In Odisha, rice is grown under diverse ecosystems with a range of management practices

4 suited to a wide range of edaphic and climatic conditions. Immense diversity in growth

5 habits makes classification and characterization of the rice environments a challenging

6 task. Classification of rice lands on the basis of some important traits that influence rice

7 productivity is essential for varietal development and formulation of a package of

8 practices for crop management.

9 The development of improved varieties fulfilling the varietal requirements of the

10 three broad rice ecosystems dates back to the late 1930s. Breeding for short high-yielding

11 varieties was accelerated after the introduction of two short-height varieties, TN 1 from

12 Taiwan and IR8 developed at IRRI, into India in 1965 and 1966, respectively. These two

13 varieties of exotic origin ushered in a revolution in rice production and were extensively

14 used in hybridization programs for the indigenous development of high-yielding rice

15 varieties, primarily for irrigated lands and for rainfed uplands and medium lands. Varietal

16 improvement for lowlands was intensified in the late seventies. Altogether, 55 rice

17 varieties have been released during the last 40 years and these are shown in Table 6.

Of the 55 varieties, only a few have gained popularity among the farmers of

21 Odisha and neighboring states and are cultivated in a sizable area. Part of the reason for

22 the non-adoption of these high-yielding varieties by farmers could be the limited attention

23 given to production planning and targeting to increase productivity in the different

24 domains and stress regions. The identification of stress-prone areas, including those with 
1 water stress and floods, along with the appropriate management practices for each

2 domain can help rice farmers adopt to various rice ecosystems as well as in disseminating

3 technologies adapted to local needs. Moreover, this information could be used to develop

4 stress-adaptive management techniques like SRI, to promote stress tolerant rice varieties

5 and technologies focusing on the most vulnerable areas where drought is most severe and

6 where rainfed rice production is the major livelihood of the farmers. These production

7 domains are also niche areas for studying and developing adaptation strategies due to

8 climate change and develop climate change ready varieties. C4 rice could be one such

9 future product.

\section{$11 \quad 6.0$ Conclusions}

12 This study identified the changes in rice-growing areas in Odisha due to floods and water

13 scarcity. First, a baseline rice map of Odisha was produced for 2000 to 2010 with an

14 estimation of rice area under different classes. Accuracy was determined by correlating

15 the MODIS-derived rice areas with field-plot data and sub-national statistics obtained

16 from Odisha's Ministry of Agriculture. The $\mathrm{R}^{2}$ values were $90 \%$ at the district level. In

172002 , rice area was damaged by $5 \%$ compared with the 10 -year mean due to a severe

18 incidence of drought as indicated by the low rainfall and low NDVI in drought-affected

19 areas. During the last eleven years the rice growing area has increased by 791,715 ha.

20 The overall accuracies (correctness) of the six rice classes varied from $76 \%$ to $100 \%$.

21 However, rice versus non-rice accuracies exceeded 90\%. Almost all intermixing was only

22 between rice classes. We recommend these methods and protocols for mapping stress- 
1 prone rice environments in other countries using time-series satellite sensor data at

2 various resolutions.

3 Mapping stress prone areas is very important to understand rice researchers and planning

4 departments for sustainable rice development and livelihoods. Precise up-to-date land use

5 change maps are important inputs for promoting stress-tolerant varieties to increase rice

6 production. A significant reduction in rice area and production in 2002 and 2006 (as

7 indicated by the remote-sensing analysis and national statistics) reveals a need to further

8 focus on the development and promotion of drought-tolerant rice varieties and the

9 associated crop management practices for rainfed environments. This will help reduce

10 production losses and yield variability over the years, thus minimizing the negative

11 impacts of drought and other abiotic stresses. In technology development, differences in

12 target domain characteristics and local technological needs should be considered. Remote

13 sensing techniques were useful for assessing the impact of early-season drought by

14 mapping reductions in rice area but not for estimating a reduction in crop yields caused

15 by mid- and later-season drought. Future research should focus on designing suitable

16 techniques to measure the impact of terminal drought (yield effect) in combination with

17 other suitable methods not (Such as owing to its unique interaction with water/soil,

18 RADAR remote sensing might have potential application in the mapping of irrigated rice

19 areas) covered in the current study. Similarly, future studies that encompass effects of

20 other non-climatic stresses may provide more insights.

\section{Acknowledgments}


1 This research was funded by the Bill \& Melinda Gates Foundation project "Stress-

2 Tolerant Rice for Africa and South Asia" (STRASA) and implemented by the

3 International Rice Research Institute, Philippines. We would like to thank Dr. Debdutt

4 Behura, Agriculture Department of Odisha, for providing up-to-date rice statistics on the 5 study area.

6

\section{References:}

Abderrahman, W.A., Bader, T.A., 1992. Remote sensing application to the management of agricultural drainage water in severely arid region: A case study. Remote Sensing of Environment 42, 239-246.

Ambast, S.K., Keshari, A.K., Gosain, A.K., 2002. Satellite remote sensing to support management of irrigation systems: Concepts and approaches. Irrigation and Drainage 51, 25-39

Biggs, T.W., Gangadhara Rao, P., Bharati, L., 2010. Mapping agricultural responses to water supply shocks in large irrigation systems, southern India. Agricultural Water Management 97, 924-932.

Congalton, R.G., Green, K., 1999. Assessing the accuracy of remotely sensed data: principles and practices. New York: Lewis.

Das, S.R., Bastia, D.N., 2013. Two decades of achievements of the EIRLSBN: contributions of Odisha University of Agriculture and Technology. In: B.C.Y. Collard, A.M.I., and B. Hardy (Ed.), EIRLSBN: Twenty years of achievements in rice breeding. International Rice Research Institute (IRRI), Los Baños (Philippines). 145 p. 
1 DIP, 2012. Odisha statistics, Datanet India Pvt. Ltd. http://www.odishastat.com/agriculture/. (accessed on 15 Jan2013).

3 Frolking, S., Qiu, J., Boles, S., Xiao, X., Liu, J., Zhuang, Y., Li, C., Qin, X., 2002.

4 Combining remote sensing and ground census data to develop new maps of the

5 distribution of rice agriculture in China. Global Biogeochemical Cycles 16, 380163810.

7 Fujita, K., 2009. Green Revolution in India and Its Significance in Economic 8 Development: Implications for $\quad$ Sub-Saharan 9 (http://policydialogue.org/files/events/Fujita_green_rev_in_india.pdf). (Accessed $10 \quad$ on 19 Jan 2013).

11 Gaur, A., Biggs, T.W., Gumma. M.K., P, G.R., Turral.H, 2008. Water scarcity effects on 12 equitable water distribution and land use in Major Irrigation Project - A Case 13 study in India. Journal of irrigation and Drainage Engineering 134 (1): 26-35.

14 Gautam, A.P., Webb, E.L., Shivakoti, G.P., Zoebisch, M.A., 2003. Land use dynamics 15 and landscape change pattern in a mountain watershed in Nepal. Agriculture, $16 \quad$ Ecosystems and Environment 99, 83-96.

17 Gumma, M.K., Gauchan, D., Nelson, A., Pandey, S., Rala, A., 2011a. Temporal changes 18 in rice-growing area and their impact on livelihood over a decade: A case study of 19 Nepal. Agriculture, Ecosystems and Environment 142, 382-392.

20 Gumma, M.K., Thenkabail, P.S., Hideto, F., Nelson, A., Dheeravath, V., Busia, D., Rala, 21 A., 2011b. Mapping Irrigated Areas of Ghana Using Fusion of $30 \mathrm{~m}$ and $250 \mathrm{~m}$ 22 Resolution Remote-Sensing Data. Remote Sensing 3, 816-835. 
1 Gumma, M.K., Thenkabail, P.S., Muralikrishna, I.V., Velpuri, M.N., Gangadhararao, P.T., Dheeravath, V., Biradar, C.M., Acharya Nalan, S., Gaur, A., 2011c. Changes in agricultural cropland areas between a water-surplus year and a water-deficit year impacting food security, determined using MODIS $250 \mathrm{~m}$ time-series data and spectral matching techniques, in the Krishna River basin (India). International Journal of Remote Sensing 32, 3495-3520.

IITM, 2012. Rainfall data of Odisha, Indian Institute of Tropical Meteorology. ftp://www.tropmet.res.in/pub/data/rain-series/6-epi.txt (accessed on 15 Dec 2012).

Panigrahi, D., Mohanty, P.K., Acharya, M., Senapati, P.C., 2010. Optimal utilisation of natural resources for agricultural sustainability in rainfed hill plateaus of Orissa. Agricultural Water Management 97, 1006-1016.

Sakamoto, T., Van Nguyen, N., Ohno, H., Ishitsuka, N., Yokozawa, M., 2006. Spatiotemporal distribution of rice phenology and cropping systems in the Mekong Delta with special reference to the seasonal water flow of the Mekong and Bassac rivers. Remote Sensing of Environment 100, 1-16.

Samal, P., Pandey, S., 2005. Climatic Risks in Rice Production in Coastal Orissa. Agricultural Economics Research Review . Vol. 18 (Conference No.) 2005 pp 6172. (http://ageconsearch.umn.edu/bitstream/58461/2/P-Samal.pdf).

Semwal, R.L., Nautiyal, S., Sen, K.K., Rana, U., Maikhuri, R.K., Rao, K.S., Saxena, K.G., 2004. Patterns and ecological implications of agricultural land-use changes: a case study from central Himalaya, India. Agriculture, Ecosystems and Environment 102, 81-92. 
1 Thenkabail, P.S., Biradar, C.M., Noojipady, P., Dheeravath, V., Li, Y., Velpuri, M.,

2 Gumma, M., Gangalakunta, O.R.P., Turral, H., Cai, X., Vithanage, J., Schull, M.A., Dutta, R., 2009. Global irrigated area map (GIAM), derived from remote sensing, for the end of the last millennium. International Journal of Remote Sensing 30, 3679-3733.

6 Thenkabail, P.S., Gangadhara Rao, P., Biggs, T., Gumma, M.K., Turral, H., 2007. Spectral Matching Techniques to Determine Historical Land use/Land cover (LULC) and Irrigated Areas using Time-series AVHRR Pathfinder Datasets in the Krishna River Basin, India. . Photogrammetric Engineering and Remote Sensing

11 Thenkabail, P.S., Schull, M., Turral, H., 2005. Ganges and Indus river basin land use/land cover (LULC) and irrigated area mapping using continuous streams of MODIS data. Remote Sensing of Environment 95, 317-341.

14 TRMM, 2012. Tropical Rainfall Measuring Mission. http://trmm.gsfc.nasa.gov/ (accessed on 12 Dec 2011). 
3 Figure 1: The Odisha study area, showing major rivers and state and district boundaries.

4 There are 114 field-plot locations where rice crop type, cropping intensity, water source

5 (irrigated vs rainfed), and a number of other parameters (e.g., digital photos, land cover

6 distribution) were also collected.

7 Figure 2: Overview of the methodology for dissemination.

8 Figure 3: Spatial distribution of rice (derived from 2000-01 to 2010-11 MODIS

9 composite)

10 Figure 4: The 10 years (years 2000 to 2009) of mean rice areas of Odisha derived using

11 MODIS $250 \mathrm{~m}$ were compared with mean rice areas from agricultural census data.

12 (Administrative boundaries are shown in Fig. 1.)

13 Figure 5: Spatial distribution of rice areas and areas affected by various stresses.

14 Figure 6: Identification of stress-prone areas and the number of years in which stresses

15 occurred during the last 10 years.

16

\section{Tables:}

Table 1: MODIS Terra 2-band reflectance data and characteristics used in this study ${ }^{1}$.

Table 2: Rice areas (ha) with various ecosystems generated by remote-sensing technique for 2010-11.

Table 3: Fuzzy accuracy assessment from field-plot data. Values in the table indicate the $\%$ of field-plot windows in each class with a given correctness $\%$.

Table 4: Rice areas affected by various stresses across Odisha (water deficiency and floods).

Table 5: Stress-prone areas at district level with number of times affected during the last 10 years and total rice areas derived from remote-sensing data (year 2010-11). 


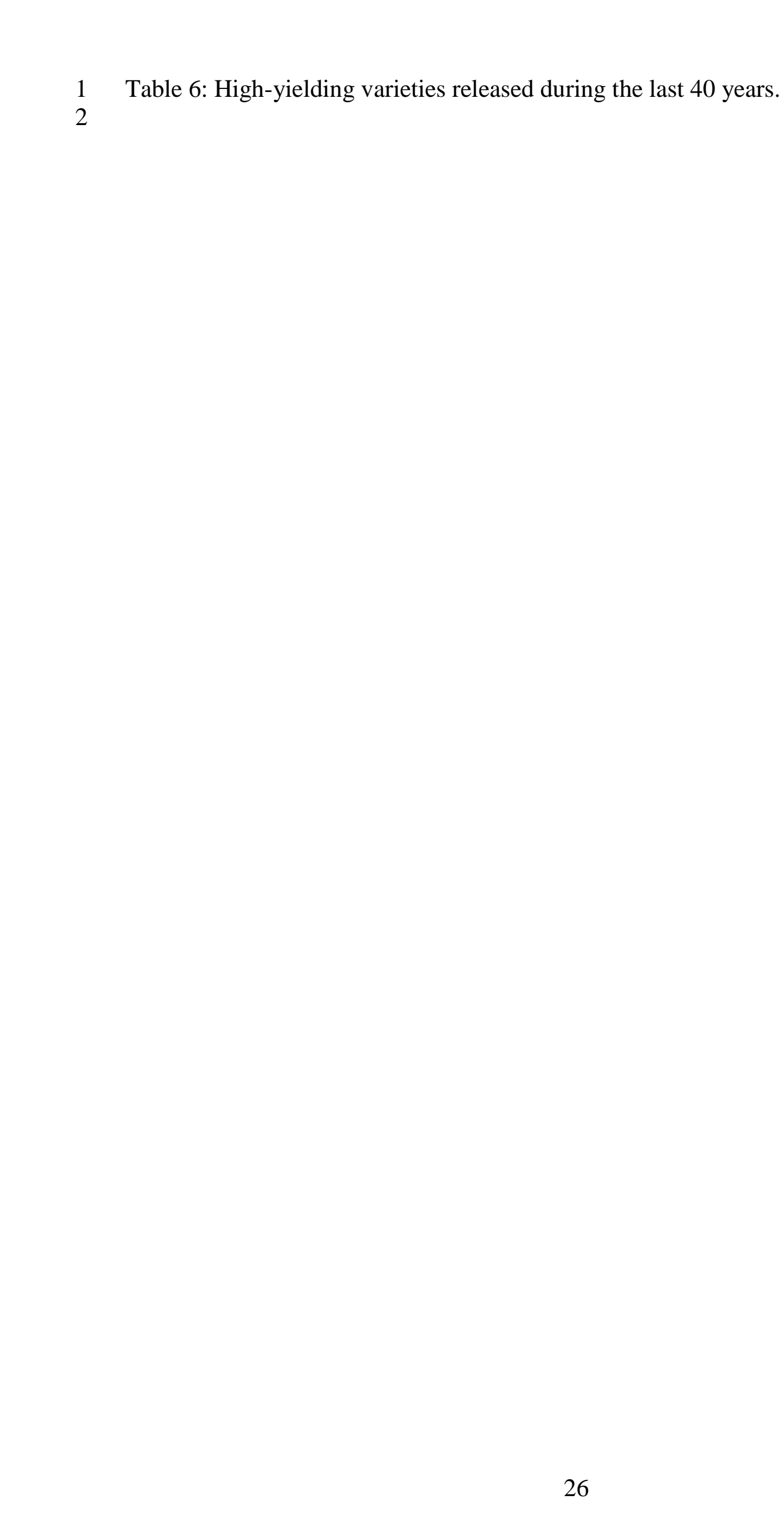


Figures

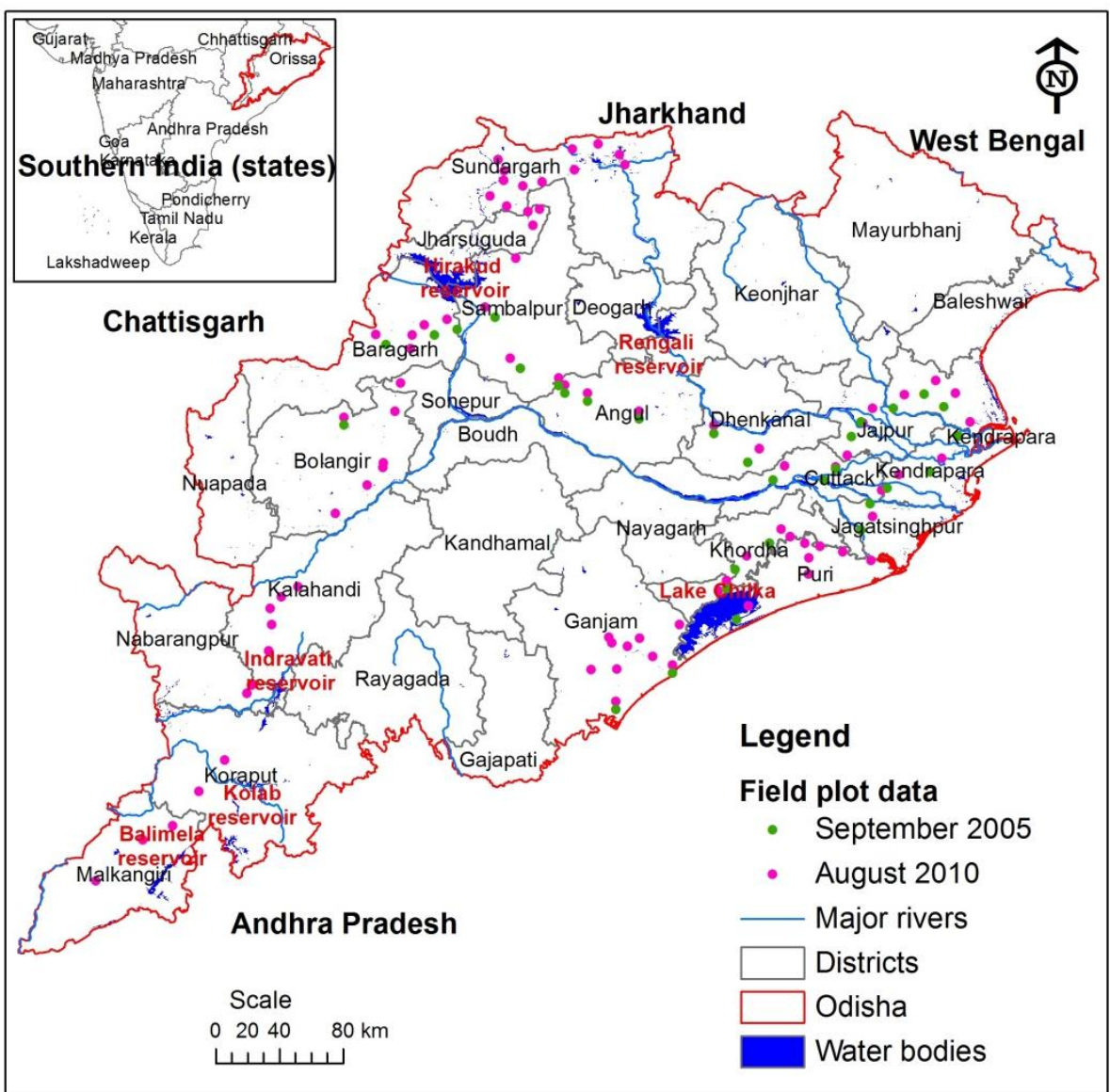

Figure 1: The Odisha study area, showing major rivers and state and district boundaries. 4 There are 114 field-plot locations where rice crop type, cropping intensity, water source 5 (irrigated vs rainfed), and a number of other parameters (e.g., digital photos, land cover 6 distribution) were also collected. 
Figure 3: Spatial distribution of rice (derived from 2010-11 MODIS composite).

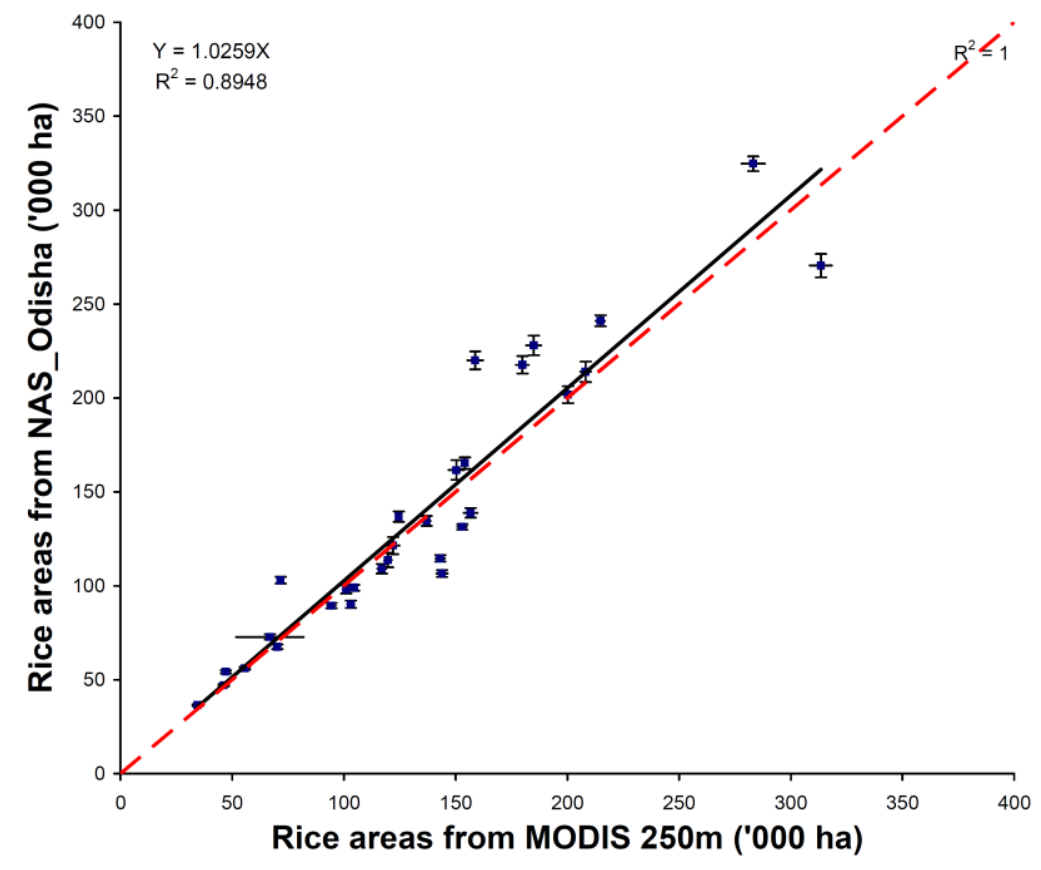

5 Figure 4: The 10 years (years 2000 to 2009) of mean rice areas of Odisha derived using

6 MODIS $250 \mathrm{~m}$ were compared with mean rice areas from agricultural census data (kharif 


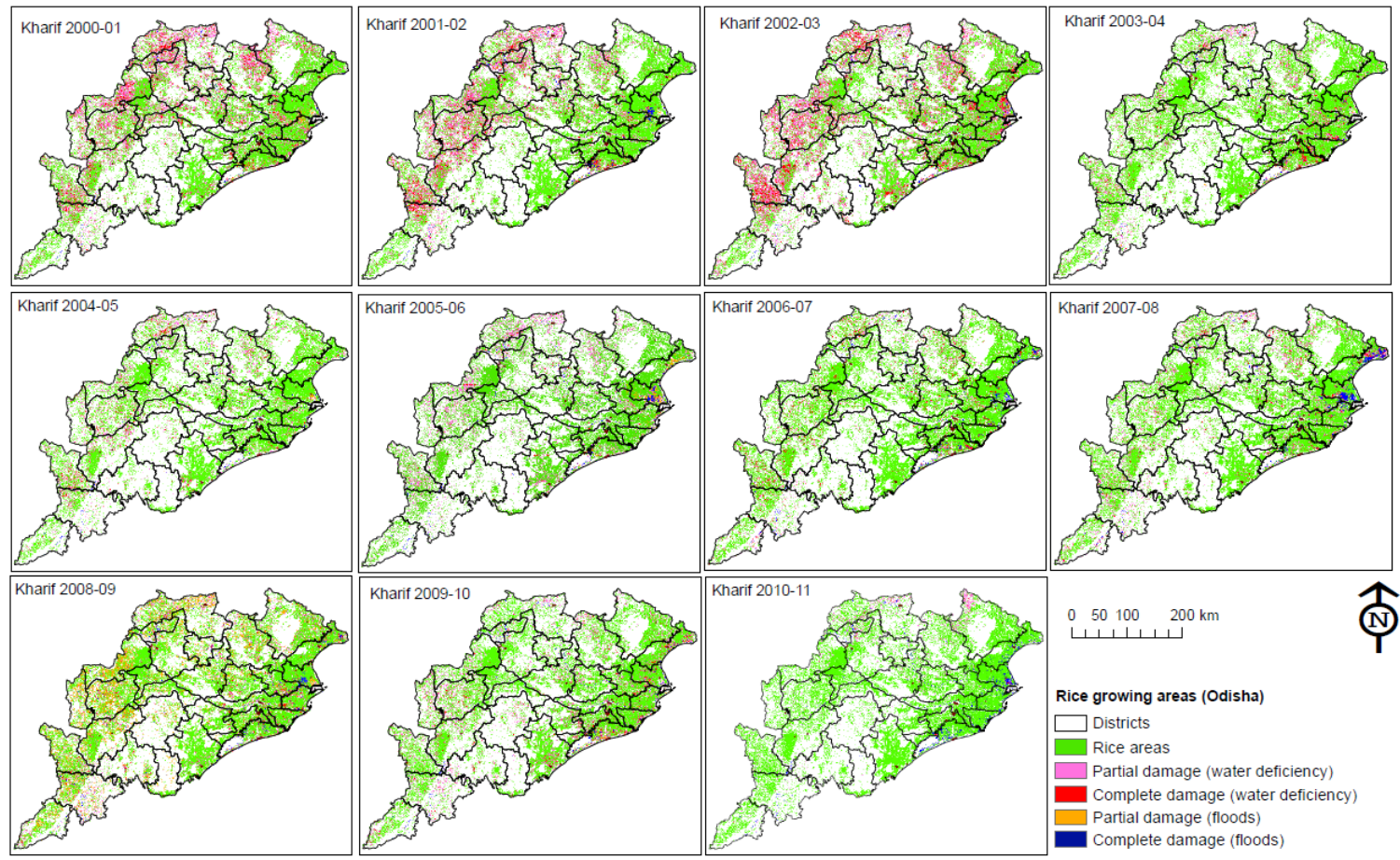


1 occurred during the last 10 years. b) Drought years identified during 2000, 2002 and 2 2009: compared with rainfall $(\mathrm{mm})$ and normalized difference vegetation indices (NDVI) 3 for normal year 2001 and severe drought years (2002). c) Flood areas during 2006, 2007 4 and 2008: compared with rainfall $(\mathrm{mm})$ and normalized difference vegetation indices 5 (NDVI) for normal year 2005 and flood year (2002). d and e are example for drought and 6 submergence prone areas identified using high resolution imagery. 
Tables:

2

3 Table 1: MODIS Terra 2-band reflectance data and characteristics used in this study ${ }^{1}$.

\begin{tabular}{lccl}
\hline & & \multicolumn{3}{c}{ MOD09A1 product $^{1}$} \\
\hline $\begin{array}{c}\text { MODIS } \\
\text { bands }^{2}\end{array}$ & $\begin{array}{c}\text { Band width } \\
(\mathrm{nm})^{3}\end{array}$ & $\begin{array}{c}\text { Band center } \\
(\mathrm{nm})^{3}\end{array}$ & Potential application $^{4}$ \\
\hline 1 & $620-670$ & 648 & $\begin{array}{l}\text { Absolute land cover transformation, vegetation } \\
\text { chlorophyll }\end{array}$ \\
2 & $841-876$ & 858 & $\begin{array}{l}\text { Cloud amount, vegetation land cover } \\
\text { transformation }\end{array}$ \\
\hline
\end{tabular}

Note: $1=$ of the 36 MODIS bands, the 7 bands reported here are specially processed for land studies.

2 = MODIS bands are rearranged to follow the electromagnetic spectrum (e.g., blue band 3 followed by green band

4).

$3=$ nanometers.

4 = taken from MODIS Web site (http://modis.gsfc.nasa.gov/data/dataprod/index.php).

4

5 Table 2: Rice areas (ha) with various ecosystems generated by remote-sensing technique

6 for 2010-11. (Note: SC: single crop; DC: double crop; TC: triple crop; SW: surface

7 water; GW: groundwater

8

\begin{tabular}{|c|c|c|c|c|}
\hline Rice class\# & $\begin{array}{c}\text { Full pixel } \\
\text { area }\end{array}$ & $\begin{array}{l}\text { Rice } \\
\text { area } \\
\text { fraction }\end{array}$ & $\begin{array}{l}\text { Sub-pixel } \\
\text { rice area } \\
\text { (ha) }\end{array}$ & $\%$ \\
\hline 01. Rainfed-SC-kharif-winter-rice & $21,04,388$ & $79 \%$ & $16,65,042$ & $39 \%$ \\
\hline 02. Rainfed-supplemental-SC-kharif-winter-rice & $2,28,463$ & $84 \%$ & $1,91,165$ & $4 \%$ \\
\hline 03. Rainfed-SC-kharif-winter-rice (mixed other crops) & $8,83,969$ & $62 \%$ & $5,52,457$ & $13 \%$ \\
\hline 04. Irrigated-SC-kharif-winter-rice & $11,43,631$ & $87 \%$ & $9,92,908$ & $23 \%$ \\
\hline 05. Irrigated-DC-kharif-autumn \& summer-rice & $9,27,328$ & $89 \%$ & $8,22,302$ & $19 \%$ \\
\hline 06. Irrigated-TC-kharif-autumn-winter \& summer-rice & 69,908 & $89 \%$ & 61,990 & $1 \%$ \\
\hline Total kharif-autumn-Irrigated-rice (class 6,7) & & & $8,84,292$ & \\
\hline Kharif-winter-rainfed rice (classes 1,2 and 3 ) & & & $24,08,664$ & $70 \%$ \\
\hline Kharif-winter-irrigated rice (classes 4 and 7) & & & $10,54,899$ & $30 \%$ \\
\hline Total kharif-autumn-rice & & & $34,63,562$ & \\
\hline Rabi-summer-Irrigated rice (classes 6 and 7) & & & $8,84,292$ & \\
\hline Total rice area (kharif + rabi) & & & $52,32,146$ & \\
\hline
\end{tabular}


Table 3: Fuzzy accuracy assessment from field-plot data. Values in the table indicate the $\%$ of field-plot windows in each class with a given correctness $\%$.

\begin{tabular}{|c|c|c|c|c|c|c|c|c|c|c|c|c|}
\hline \multicolumn{13}{|c|}{ Reference data (field-plot data) } \\
\hline Classified data & $\begin{array}{l}01 . \\
\text { Rainfed } \\
\text {-SC- } \\
\text { kharif- } \\
\text { winter- } \\
\text { rice }\end{array}$ & $\begin{array}{l}\text { 02. Rainfed- } \\
\text { supplementa } \\
\text { 1-SC-kharif- } \\
\text { winter-rice }\end{array}$ & $\begin{array}{l}03 . \\
\text { Rainfed- } \\
\text { SC- } \\
\text { kharif- } \\
\text { winter- } \\
\text { rice } \\
\text { (mixed } \\
\text { other } \\
\text { crops) }\end{array}$ & $\begin{array}{l}04 . \\
\text { Irrigated } \\
\text {-SC- } \\
\text { kharif- } \\
\text { winter- } \\
\text { rice }\end{array}$ & $\begin{array}{l}05 . \\
\text { Irrigated- } \\
\text { DC- } \\
\text { kharif- } \\
\text { autumn } \\
\& \\
\text { summer- } \\
\text { rice }\end{array}$ & $\begin{array}{l}06 . \\
\text { Irrigated- } \\
\text { TC- } \\
\text { kharif- } \\
\text { autumn- } \\
\text { winter \& } \\
\text { summer- } \\
\text { rice }\end{array}$ & $\begin{array}{l}07 . \\
\text { Other } \\
\text { classe } \\
\mathrm{s}\end{array}$ & $\begin{array}{l}\text { Row } \\
\text { Tota } \\
1\end{array}$ & $\begin{array}{l}\text { Numbe } \\
\mathrm{r} \\
\text { Correct }\end{array}$ & $\begin{array}{l}\text { Producer } \\
\text { s } \\
\text { Accurac } \\
\text { y }\end{array}$ & $\begin{array}{l}\text { Users } \\
\text { Accurac } \\
\mathrm{y}\end{array}$ & $\begin{array}{l}\text { Kapp } \\
\text { a }\end{array}$ \\
\hline $\begin{array}{l}\text { 01. Rainfed-SC-kharif- } \\
\text { winter-rice }\end{array}$ & 19 & 1 & 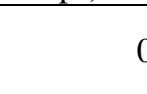 & 3 & 2 & 0 & 0 & 25 & 19 & $86 \%$ & $76 \%$ & $69 \%$ \\
\hline $\begin{array}{l}\text { 02. Rainfed- } \\
\text { supplemental-SC-kharif- } \\
\text { winter-rice }\end{array}$ & 0 & 0 & c & 0 & 0 & 0 & 0 & 0 & 0 & --- & --- & $0 \%$ \\
\hline $\begin{array}{l}\text { 03. Rainfed-SC-kharif- } \\
\text { winter-rice (mixed other } \\
\text { crops) }\end{array}$ & 0 & 0 & 5 & 0 & 0 & 0 & 0 & 5 & 5 & $83 \%$ & $100 \%$ & $100 \%$ \\
\hline $\begin{array}{l}\text { 04. Irrigated-SC-kharif- } \\
\text { winter-rice }\end{array}$ & 0 & 0 & c & 14 & 1 & 0 & 1 & 16 & 14 & $58 \%$ & $88 \%$ & $83 \%$ \\
\hline $\begin{array}{l}\text { 05. Irrigated-DC-kharif- } \\
\text { autumn \& summer-rice }\end{array}$ & 2 & 0 & 1 & 0 & 15 & 0 & 0 & 18 & 15 & $75 \%$ & $83 \%$ & $79 \%$ \\
\hline $\begin{array}{l}\text { 06. Irrigated-TC-kharif- } \\
\text { autumn-winter \& } \\
\text { summer-rice }\end{array}$ & 0 & 0 & c & 0 & 1 & 6 & 0 & 7 & 6 & $100 \%$ & $86 \%$ & $85 \%$ \\
\hline 07. Other classes & 1 & 1 & c & 7 & 1 & 0 & 15 & 25 & 15 & --- & --- & $52 \%$ \\
\hline Column Total & 22 & 2 & 6 & 24 & 20 & 6 & 16 & 96 & 74 & & & \\
\hline
\end{tabular}


Table 4: Rice areas affected by various stresses across Odisha (water deficiency and floods).

\begin{tabular}{|c|c|c|c|c|c|c|c|c|c|c|c|}
\hline \multirow[b]{2}{*}{ Year } & \multirow[b]{2}{*}{$\begin{array}{c}\text { MODIS } \\
\text { rice area } \\
\text { (ha) }\end{array}$} & \multicolumn{2}{|c|}{ Partial damage (ha) } & \multicolumn{2}{|c|}{ Complete damage (ha) } & \multicolumn{2}{|c|}{ Partial damage $\%$} & \multicolumn{2}{|c|}{ Complete damage $\%$} & \multicolumn{2}{|c|}{$\begin{array}{c}\text { TRMM rainfall }(\mathrm{mm}) \\
\text { (affected areas) }\end{array}$} \\
\hline & & $\begin{array}{c}\text { Water } \\
\text { deficiency }\end{array}$ & Submergence & $\begin{array}{c}\text { Water } \\
\text { deficiency }\end{array}$ & Submergence & $\begin{array}{c}\text { Water } \\
\text { deficiency }\end{array}$ & Submergence & $\begin{array}{c}\text { Water } \\
\text { deficiency }\end{array}$ & Submergence & $\begin{array}{c}\text { Water } \\
\text { deficiency }\end{array}$ & Submergence \\
\hline 2000 & $3,494,139$ & 744,277 & 10,568 & 408,779 & 8,160 & $21.3 \%$ & $0.3 \%$ & $11.7 \%$ & $0.2 \%$ & -396 & 50 \\
\hline 2001 & $3,667,406$ & 601,868 & 17,042 & 339,437 & 15,163 & $16.4 \%$ & $0.5 \%$ & $9.3 \%$ & $0.4 \%$ & -8 & 16 \\
\hline 2002 & $3,291,008$ & 840,582 & 3,345 & 508,001 & 1,126 & $25.5 \%$ & $0.1 \%$ & $15.4 \%$ & $0.0 \%$ & -413 & 82 \\
\hline 2003 & $4,160,843$ & 321,368 & 8,268 & 160,181 & 4,246 & $7.7 \%$ & $0.2 \%$ & $3.8 \%$ & $0.1 \%$ & 264 & 497 \\
\hline 2004 & $4,071,079$ & 419,382 & 4,692 & 178,849 & 1,121 & $10.3 \%$ & $0.1 \%$ & $4.4 \%$ & $0.0 \%$ & -171 & 269 \\
\hline 2005 & $4,123,355$ & 369,499 & 15,157 & 156,517 & 8,494 & $9.0 \%$ & $0.4 \%$ & $3.8 \%$ & $0.2 \%$ & -5 & 522 \\
\hline 2006 & $3,782,380$ & 586,205 & 15,383 & 267,238 & 7,505 & $15.5 \%$ & $0.4 \%$ & $7.1 \%$ & $0.2 \%$ & 76 & 255 \\
\hline 2007 & $4,108,566$ & 351,556 & 27,964 & 155,451 & 21,349 & $8.6 \%$ & $0.7 \%$ & $3.8 \%$ & $0.5 \%$ & 0 & 481 \\
\hline 2008 & $4,016,866$ & 413,767 & 76,397 & 179,382 & 13,905 & $10.3 \%$ & $1.9 \%$ & $4.5 \%$ & $0.3 \%$ & 174 & 535 \\
\hline 2009 & $3,992,179$ & 472,484 & 41,868 & 191,743 & 30,261 & $11.8 \%$ & $1.0 \%$ & $4.8 \%$ & $0.8 \%$ & -140 & 335 \\
\hline 2010 & $4,285,854$ & 287,620 & 21,332 & 106,700 & 8,823 & $6.7 \%$ & $0.5 \%$ & $2.5 \%$ & $0.2 \%$ & -96 & 50 \\
\hline
\end{tabular}


Table 5: Stress-prone areas at district level with number of times affected during the last 10 years and total rice areas derived from remote-sensing data (year 2010-11).

\begin{tabular}{|c|c|c|c|c|c|c|c|}
\hline \multirow{2}{*}{ District } & \multirow{2}{*}{$\begin{array}{l}\text { Total rice } \\
\text { area (ha) }\end{array}$} & \multicolumn{3}{|c|}{ Water deficiency (area in ha) } & \multicolumn{3}{|c|}{ Flood (area in ha) } \\
\hline & & $1-2$ years & $2-5$ years & $>5$ years & $2-3$ years & 3-6 years & $>6$ years \\
\hline Angul & 126,508 & 42,750 & 31,013 & 6,700 & 1,706 & 1,094 & 231 \\
\hline Baleshwar & 237,143 & 113,213 & 36,006 & 4,038 & 49,438 & 18,269 & 2,338 \\
\hline Baragarh & 220,275 & 122,313 & 103,013 & 13,075 & 419 & 294 & 81 \\
\hline Bhadrak & 178,378 & 82,975 & 24,269 & 1,250 & 61,981 & 52,263 & 7,263 \\
\hline Bolangir & 161,707 & 92,956 & 69,975 & 12,400 & 256 & 150 & 69 \\
\hline Boudh & 63,644 & 23,469 & 15,744 & 2,025 & 456 & 506 & 231 \\
\hline Cuttack & 164,208 & 69,469 & 40,475 & 4,538 & 4,338 & 2,563 & 556 \\
\hline Deogarh & 45,578 & 17,050 & 15,088 & 4,131 & 994 & 719 & 94 \\
\hline Dhenkanal & 137,114 & 47,194 & 28,825 & 7,681 & 925 & 806 & 131 \\
\hline Gajapati & 36,157 & 10,381 & 3,363 & 313 & 100 & 106 & - \\
\hline Ganjam & 341,031 & 124,169 & 45,919 & 4,944 & 594 & 156 & - \\
\hline Jagatsinghpur & 103,409 & 34,313 & 18,331 & 2,244 & 4,169 & 750 & 25 \\
\hline Jajpur & 162,248 & 62,056 & 39,463 & 4,425 & 20,538 & 6,206 & 513 \\
\hline Jharsuguda & 64,677 & 24,475 & 24,600 & 3,175 & 2,663 & 1,813 & 669 \\
\hline Kalahandi & 186,920 & 104,625 & 88,200 & 13,375 & 744 & 506 & 44 \\
\hline Kandhamal & 45,744 & 17,944 & 10,550 & 1,844 & 13 & - & - \\
\hline Kendrapara & 142,725 & 56,206 & 25,225 & 1,988 & 24,294 & 8,169 & 1,669 \\
\hline Keonjhar & 220,853 & 68,600 & 71,500 & 16,481 & 7,300 & 1,013 & 25 \\
\hline Khordha & 125,814 & 46,406 & 26,431 & 2,956 & 4,563 & 1,863 & 1,106 \\
\hline Koraput & 129,230 & 51,500 & 40,275 & 7,456 & 1,788 & 781 & 94 \\
\hline Malkangiri & 99,617 & 33,244 & 12,131 & 2,413 & 575 & 300 & - \\
\hline Mayurbhanj & 303,301 & 118,619 & 72,294 & 10,931 & 1,663 & 275 & - \\
\hline Nabarangpur & 176,627 & 53,506 & 65,025 & 10,763 & 475 & 413 & 188 \\
\hline Nayagarh & 103,648 & 40,025 & 22,888 & 3,400 & 956 & 363 & 113 \\
\hline Nuapada & 76,874 & 38,938 & 37,550 & 6,281 & 144 & 94 & - \\
\hline
\end{tabular}


Puri 148,028 61,625 31,231

$62,851 \quad 29,944$

11,713

3,319

19,875

8,606

2,300

Sambalpur

$147,198 \quad 61,106$

42,025

1,169

25

25

Sonepur

103,120

46,175

21,381

5,825

1,981

1,188

394

Sundargarh

171,225

66,744

89,300

2,700

663

344

81

Sundargarh

.

Table 6. High-yielding varieties released during the last 40 years

\begin{tabular}{ccl}
\hline Year of release & No. of releases & \multicolumn{1}{c}{ Variety } \\
\hline 1969 & 1 & Jagannath \\
1971 & 3 & Hema, Kumar, Rajeswari \\
1976 & 2 & Parijat, Suphala \\
1980 & 3 & Keshari, Subhadra, Jajati \\
1983 & 5 & Shankar, Rudra, Sarathi, Daya, Pratap \\
1985 & 3 & Pathara, Gouri, Rambha \\
1988 & 4 & Shrabani, Lalat, Ananga, Bhuban \\
1992 & 12 & Nilagiri, Khandagiri, Badami, Ghanteswari, Birupa, \\
& & Bhanja, Samant, Meher, Manik, Urbasi, Mahalaxmi, \\
& & Kanchan \\
1999 & 12 & Lalitagiri, Udayagiri, Bhoi, Sebati, Konarka, Kharavela, \\
& & Gajapati, Surendra, Prachi, Mahanadi, \\
& & Ramachandi \\
2002 & 1 & Jagabandhu \\
2005 & 4 & Sidhanta, Jogesh, Pratikshya, Upahar \\
2009 & 1 & Manaswini \\
2010 & 1 & Ranidhan \\
& & Mandakini, Tejaswini, Mrunalini
\end{tabular}

